\title{
PENGARUH PENGUNAAN PROBIOTIK Lactobacillus brevis DAN \\ PREBIOTIK OLIGOSAKARIDA (Fructooligosakarida-Galaktoologosakarida) \\ TERHADAP GAMBARAN DARAH PATIN SIAM (Pangasionodon hypophtalmus) YANG DIINFEKSI Aeromonas hydrophila
}

\author{
Oleh: \\ Yuke Eliyani*, Widanarni**, Dinamella Wahjuningrum** \\ *Dosen Jurusan Penyuluhan Perikanan Sekolah Tinggi Perikanan \\ **Dosen Institut Pertanian Bogor
}

\begin{abstract}
ABSTRAK
Penelitian ini bertujuan untuk mengetahui pengaruh pemberian probiotik Lactobacillus brevis, prebiotik oligosakarida (FructooligosakaridaGalaktooligosakarida) terhadap nilai hemoglobin, hematokrit serta diferensial leukosit patin siam (Pangasionodon hypophthalmus) yang diinfeksi bakteri Aeromonas hydrophila. Uji yang dilakukan meliputi persiapan bakteri probiotik dan A.hydrophila, analisis prebiotik (oligosakarida), uji in vitro, dan uji in vivo. Parameter uji yang diamati selama penelitian adalah hemoglobin, hematokrit, serta diferensial leukosit. Penelitian terdiri dari lima perlakuan dengan masing-masing tiga ulangan, yaitu kontrol (+), kontrol (-), pemberian probiotik (Pro), pemberian prebiotik (Pre), pemberian probiotik ditambah prebiotik (Sin). Penelitian ini menggunakan Rancangan Acak Lengkap (RAL) dengan satu faktor. Data dianalisis dengan sidik ragam (ANOVA) pada selang kepercayaan 95\%. Perbedaan antar perlakuan dilanjutkan dengan uji Duncan menggunakan program Xl-stat. Hasil pengamatan pada parameter hemoglobin, hematokrit, serta diferensial leukosit, berbeda nyata $(p<0.05)$ dengan kontrol pada beberapa waktu pengamatan.
\end{abstract}

Kata kunci : probiotik, prebiotik, sinbiotik, Lactobacillus brevis, Aeromonas hydrophila, Pangasionodon hypophthalmus

\section{PENDAHULUAN}

Bakteri Aeromonas hydrophilla merupakan salah satu patogen yang banyak ditemui dalam budidaya ikan air tawar, diantaranya adalah pada pemeliharaan patin siam (Pangasionodon hypophthalmus). Wartono et al., (2010) menyatakan bahwa tingkat kematian benih patin akibat MAS dapat mencapai $40-80 \%$.
A.hydrophila memproduksi faktorfaktor virulensi berupa eksotoksin yang penting dalam patogenitas, salah satunya adalah enzim proteolitik yang dapat merusak dinding intestin inang hingga terjadi oedema. Gejala serangan bakteri ini adalah penimbunan cairan dalam rongga perut (abdominal dropsy), luka pada kulit dan otot (Rey et al., 2009). 
Berbagai cara telah dilakukan spesies dan 27 subspesies (Bernardeau untuk mengatasi penyakit ini, et al., 2008).

diantaranya dengan antibiotika. Prebiotik didefinisikan sebagai Kendala yang terjadi adalah timbulnya bahan pangan yang tidak dicerna oleh dampak resisten bakteri ini terhadap inang, dapat difermentasi oleh antibiotika yang digunakan, sehingga mikrobiota saluran pencernaan serta dicari alternatif lain yaitu penggunaan mampu secara selektif menstimulasi probiotik, prebiotik serta gabungan pertumbuhan dan aktivitas bakteri keduanya.

\section{Probiotik merupakan}

mikroorganisme non-patogen, mampu mentoleransi garam empedu serta nilai pH rendah, dapat hidup dan berkembang biak pada sistem pencernaan, membentuk koloni di permukaan epitel usus, serta dapat menghasilkan enzim pencernaan secara ekstraseluler. Selain itu probiotik mampu menjaga keseimbangan mikroba dalam usus, mengeliminasi mikrooganisme yang merugikan, dapat diproduksi secara masal, serta dapat berada dalam kondisi stabil selama masa penyimpanan (Merrifield et al., 2010).

Lebih lanjut Hernandez et al., (2012) menyatakan bahwa salah satu jenis bakteri probiotik adalah golongan Lactobacillus yang memiliki kemampuan untuk hidup dan berkembang biak dalam sistem pencernaan (toleran terhadap enzim amilase, nilai $\mathrm{pH}$ rendah, serta bertahan terhadap sekresi garam empedu). Lactobacillus merupakan bakteri gram positif berbentuk batang, memiliki karakter tergantung spesies seperti obligat/fakultatif dan homo/heterofermentatif. Lactobacillus merupakan kelompok bakteri heterogenus yang terdiri dari 135 pencernaan. Menurut Gropper et al., (2009), prebiotik berperan sebagai substrat untuk meningkatkan pertumbuhan bakteri menguntungkan atau yang bermanfaat bagi kesehatan inang sehingga menghambat perkembangan bakteri patogen. Prebiotik umumnya merupakan golongan polisakarida dan oligosakarida. Bahan ini dapat mendorong pertumbuhan bakteri asam laktat dalam usus. Inulin, fructooligosaccharide (FOS), galactooligosaccharide (GOS), lactulosa dan polydextosa adalah bahan-bahan prebiotik.

Gabungan antara prebiotik dan probiotik dikenal dengan sinbiotik. Keuntungan dari sinbiotik ini adalah pertumbuhan dari probiotik menjadi lebih baik karena terlebih dahulu telah mendapat pakan dari prebiotik. Hasil penelitian Merrifield et al., (2010) menunjukkan bahwa suplemen sinbiotik (kombinasi probiotik dari golongan bakteri asam laktat dan prebiotik oligosakarida), berpengaruh positif pada pertumbuhan dan aktivitas bakteri pencernaan ikan salmon 


\section{METODE PENELITIAN}

\section{Waktu dan Tempat Penelitian}

Penelitian dilaksanakan mulai bulan Oktober sampai dengan Desember 2012 di Laboratorium Kesehatan Ikan, Institut Pertanian Bogor; Sekolah Tinggi Perikanan Jurusan Penyuluhan Perikanan Bogor; dan Balai Besar Pengembangan Budidaya Air Tawar Sukabumi.

\section{Metode Penelitian}

Kegiatan Penelitian meliputi persiapan bakteri probiotik dan A.hydrophila, analisis prebiotik (oligosakarida), uji in vitro, dan uji in vivo.

\section{Uji in vitro}

\section{Penentuan LD50 bakteri}

\section{A.hydrophila}

Benih ikan patin siam (Pangasionodon hypophthalmus) dengan panjang rata-rata $9,1 \pm 0,19 \mathrm{~cm}$ dipelihara dalam dua belas akuarium. Padat tebar ikan adalah 10 ekor per akuarium. Penginfeksian A.hydrophila dilakukan dengan cara disuntik secara intra muskular sebanyak $0,1 \mathrm{ml} /$ ekor ikan, dengan kepadatan bakteri $10^{6}$, $10^{7}, 10^{8}$ dan $10^{9} \mathrm{CFU} / \mathrm{ml}$. Pengamatan mortalitas ikan uji dilakukan selama tujuh hari. Penghitungan LD50 menggunakan metode Reed dan Muench (1938). Berdasarkan hasil perhitungan diperoleh nilai LD50 sebesar $10^{7} \mathrm{CFU} / \mathrm{ml}$.

\section{Aktivitas antagonistik}

Aktivitas antagonistik L. brevis diuji terhadap A.hydrophila dengan metode Bauer-Kirby (1966). Isolat A.hydrophila dan L.brevis diencerkan hingga masing-masing memiliki tingkat kekeruhan sekitar $10^{7} \mathrm{CFU} / \mathrm{ml}$. Pengukuran ini dilakukan dengan menggunakan spektrofotometer pada panjang gelombang $600 \mathrm{~nm}$. A. hydrophila disebar pada media TSA sebanyak $100 \mu \mathrm{l}$. Kertas cakram (Whatman antibiotic asay paper) berdiameter $5 \mathrm{~mm}$ diletakkan di bagian permukaan media TSA kemudian ditetesi suspensi $L$. brevis sebanyak 10 $\mu 1$ dan sebagai kontrol dalam perlakuan ini digunakan larutan fisiologis. Selanjutnya media berinokulan ini diinkubasi pada suhu $29^{\circ} \mathrm{C}$ selama 24 jam. Pengukuran zona bening yang terbentuk dilakukan menggunakan jangka sorong pada 4 posisi diamater lingkaran dari setiap kertas cakram.

\section{Uji in vivo}

\section{Penyiapan pakan}

Pakan yang digunakan dalam penelitian adalah pakan komersil dengan kandungan protein $28 \%$. Bakteri probiotik dengan konsentrasi $10^{7} \mathrm{CFU} / \mathrm{ml}$ sebanyak 1\% (Putra, 2010), dan prebiotik sebanyak $2 \%$ (Mathious et al., 2006) dicampurkan pada pakan, serta menggunakan perekat berupa putih telur sebanyak $2 \%$. Pakan selanjutnya dikering-anginkan selama satu jam untuk mengurangi kelembaban. 


\section{Kondisi ikan uji}

Ikan uji yang digunakan adalah benih ikan patin siam berukuran panjang rata-rata $9,1 \pm 0,19 \mathrm{~cm}$. Ikan uji dipelihara dalam akuarium berukuran 90 x 40 x $40 \mathrm{~cm}^{3}$ dengan kepadatan 10 ekor per akuarium. Sebelum diberi perlakuan, ikan diadaptasikan terlebih dahulu selama 14 hari.

\section{Perlakuan probiotik, prebiotik, sinbiotik serta uji tantang}

Ikan uji diberi pakan secara at satiation dengan frekuensi tiga kali per hari yaitu pada pukul 7.00, 12.00 dan 17.00. Pemberian probiotik, prebiotik, sinbiotik dilakukan 1 kali per hari pada siang hari selama 30 hari pemeliharaan.

Penelitian terdiri dari lima perlakuan dengan masing-masing terdiri dari tiga ulangan sebagai berikut: Perlakuan K(-) : Pemberian pakan tanpa penambahan probiotik dan prebiotik namun tidak diinfeksi

A.hydrophila (kontrol -)

Perlakuan $\mathrm{K}(+) \quad$ : $\quad$ Pemberian pakan tanpa

penambahan probiotik dan prebiotik serta diinfeksi

A.hydrophila (kontrol +)

Perlakuan Pro : Pemberian pakan dengan penambahan probiotik sebesar 1\% (Putra, 2010)

$\begin{array}{ll} & \text { dan diinfeksi } \\ \text { Perlakuan Pre } \quad \text { A.hydrophila } & \text { Pemberian pakan } \\ & \text { dengan } \\ & \text { penambahan } \\ & \text { prebiotik sebesar } \\ & 2 \% \text { (Mahious et } \\ & \text { al., 2006) dan } \\ & \text { diinfeksi } \\ & \text { A.hydrophila } \\ \text { Perlakuan Sin } \quad \text { Pemberian pakan } \\ & \text { dengan } \\ & \text { penambahan } \\ & \text { sinbiotik } \\ & \text { (probiotik } \\ & \text { sebesar 1 \% dan } \\ & \text { prebiotik sebesar } \\ & 2 \% \text { ) dan } \\ & \text { diinfeksi }\end{array}$

A.hydrophila

\section{Parameter uji}

Parameter uji yang diamati selama penelitian adalah hemoglobin, hematokrit, serta diferensial leukosit.

\section{Parameter darah}

Pengukuran parameter darah dilakukan pada saat awal, hari ke-30, hari ke-31, hari ke-34, hari ke-36, dan hari ke-38. Adapun parameter darah yang diamati adalah sebagai berikut:

\section{Hemoglobin (Wedemeyer dan Yasutake, 1977)}

Darah dihisap dengan pipet sahli sampai mencapai $20 \mathrm{~mm}^{3}$ atau 0.2 $\mathrm{ml}$ lalu ujung pipet dibersihkan dengan tissue. Darah dalam pipet dipindahkan ke dalam tabung Hb-meter yang telah diisi $\mathrm{HCl} \quad 0.1 \quad \mathrm{~N}$ sampai skala 10 (merah), kemudian diaduk dan 
dibiarkan selama 3 sampai 5 menit. Selanjutnya akuades ditambahkan sampai warna darah dan $\mathrm{HCl}$ dalam tabung seperti warna larutan standar yang ada pada $\mathrm{Hb}$-meter. Pembacaan skala dilakukan dengan melihat permukaan cairan dan dicocokan dengan skala tabung sahli yang dilihat pada skala jalur gr \% (kuning) yang berarti banyaknya hemoglobin dalam gram per $100 \mathrm{ml}$ darah.

\section{Hematokrit (Anderson dan Siwicki, 1993)}

Salah satu ujung tabung mikrohematokrit dicelupkan ke dalam tabung yang berisi darah sehingga darah merambat secara kapiler. Ketika rambatan mencapai $3 / 4$ bagian tabung maka ujung tabung ditutup dengan cara menancapkan ujung tabung ke dalam crytoceal kira-kira sedalam $1 \mathrm{~mm}$. Tabung hematokrit tersebut selanjutnya disentrifugasi dengan kecepatan 5000 rpm selama 5 menit, lalu dilakukan pengukuran panjang bagian darah yang mengendap (a) dan panjang total volume darah yang terdapat di dalam tabung (b). Adapun kadar hematokrit dihitung dengan persamaan berikut:

\section{Diferensial leukosit (Blaxhall dan}

Daisley, 1973)

Darah diteteskan pada gelas objek bagian kanan atas, selanjutnya gelas objek yang lain diletakkan diatas tetesan darah sampai membentuk sudut sekitar $30^{\circ}$ kemudian ditarik sampai darah menyebar sepanjang tepi gelas objek pertama. Ulasan dikeringudarakan kemudian direndam dalam larutan Giemsa (1:20) selama 15-20 menit. Hasil perendaman selanjutnya dibilas dengan akuades, ditutup dengan gelas penutup dan diamati menggunakan mikroskop. Penghitungan dilakukan terhadap jenisjenis leukosit dan dihitung persentasenya.

\section{HASIL DAN PEMBAHASAN}

\section{Hemoglobin}

Hemoglobin $(\mathrm{Hb})$ merupakan bagian dari eritrosit yang memiliki kemampuan mengangkut oksigen untuk diedarkan ke seluruh tubuh. Kadar hemoglobin selama penelitian ditampilkan dalam Gambar 1.

Kadar Hematokrit ( $\%$ volume padatan darah) $=\frac{a}{b} \times 100 \%$ 


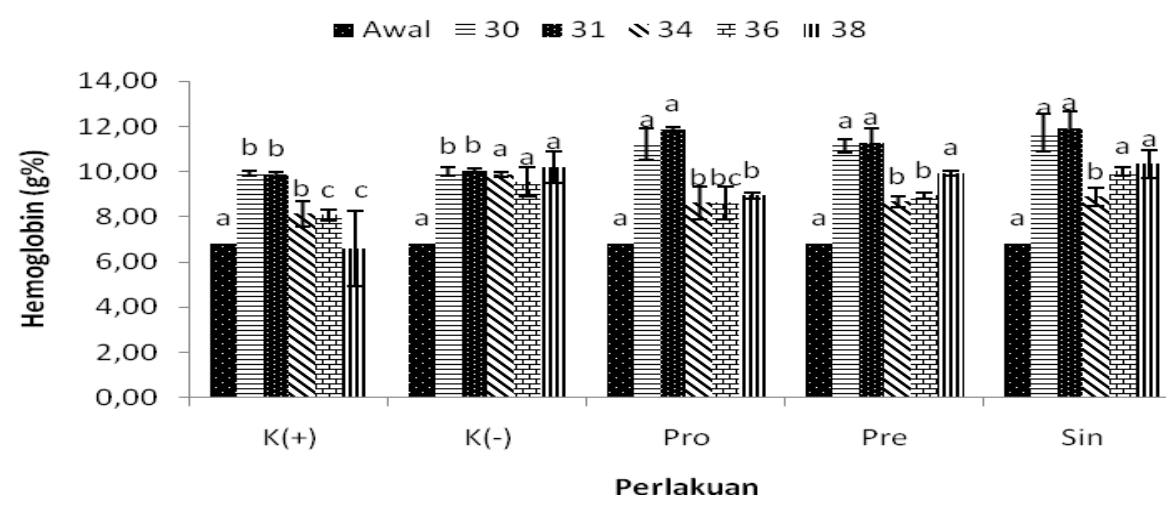

Gambar 1. Nilai hemoglobin ikan uji pada berbagai perlakuan.

Nilai hemoglobin pada awal perlakuan menunjukkan nilai yang sama untuk semua perlakuan yaitu sebesar $6,80 \pm 0,00$. Peningkatan nilai hemoglobin pada semua perlakuan terjadi pada hari ke-30. Puncak kenaikan nilai hemoglobin terjadi pada hari ke-31, hasil uji Duncan menunjukkan terdapat beda nyata antara perlakuan sinbiotik, prebiotik, perobiotik dengan $\mathrm{K}(-)$ dan $\mathrm{K}(+)$. Nilai masing-masing perlakuan adalah sebesar $\quad 11.92 \pm 0,76 ; \quad 11,87 \pm 0,64$; $11,27 \pm 12 ; 10,04 \pm 0,12$; serta $9,87 \pm 0,12$. Hemoglobin mengalami peurunan nilai mulai hari ke-34. Hasil perhitungan nilai hemoglobin pada hari ke-36 menunjukkan bahwa perlakuan Sin memberikan nilai yang berbeda nyata dengan Pre, Pro serta kontrol (+). Hal ini diduga bahwa ikan uji dengan perlakuan Sin tingkat pemulihannya lebih cepat dibandingkan perlakuan lainnya.

Perlakuan Sin, memberikan nilai hemoglobin yang tinggi dibandingkan kontrol, hal ini merupakan suatu indikasi bahwa lemak rantai pendek (SCFA) yang merupakan hasil metabolisma probiotik terhadap prebiotik memberikan kontribusi dalam menentukan jumlah hemoglobin dalam eritrosit mengingat hemoglobin adalah bentuk protein yang didalamnya terdapat ikatan Fe yang disebut dengan heme.

Penurunan hemoglobin mulai hari ke-34 diduga disebabkan oleh infeksi A.hydrophila, hal ini sesuai dengan pernyataan Harikrisnan et al., (2012) bahwa salah satu penyebab penurunan hemoglobin adalah inklusi virus, kista hemoglobin dan hemoparasit. Rey et al., (2009) menyatakan bahwa produk ekstraseluler (aerolysin, $\alpha$ - dan $\beta$ haemolysins yang dihasilkan oleh A.hydrophila strain KJ 99, mampu menurunkan kadar protein terlarut dalam darah, menyebabkan terjadinya perubahan pada hemodinamika darah ikan mulai dari dinding abdominal, peritoneum sampai dengan gastointestinal.

\section{Hematokrit}

Hematokrit merupakan nilai perbandingan antara jumlah eritrosit dengan plasma darah. Hasil 
perhitungan hematokrit ditampilkan pada Gambar 2.

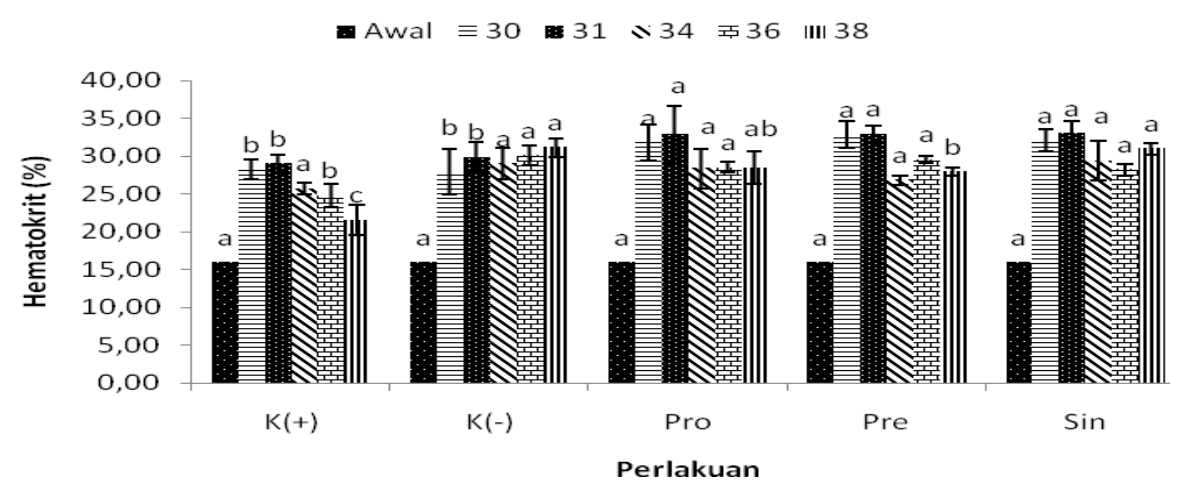

Gambar 2. Nilai hematokrit ikan uji pada berbagai perlakuan

Jumlah hematokrit pada awal pengambilan sampel memberikan nilai yang sama pada semua perlakuan yaitu

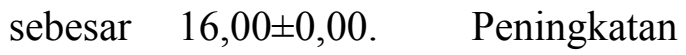
hematokrit terjadi pada hari ke-30 dan ke-31, dan hasil uji lanjut Duncan menunjukkan terjadi beda nyata antara perlakuan sinbiotik, prebiotik, probiotik dengan $\mathrm{K}(+)$ serta $\mathrm{K}(-)$. Penurunan nilai hematokrit terjadi pada hari ke-34. Nilai hematokrit pada hari ke-38 menunjukkan bahwa perlakuan Sin lebih baik dari Pre, Pro serta $\mathrm{K}(+)$. Hal ini menunjukan bahwa kondisi hematokrit pada ikan uji perlakuan Sin, mencapai tingkat recovery yang lebih cepat dibandingkan perlakuan lainnya.

Peningkatan nilai hematokrit sejalan dengan peningkatan hemoglobin serta eritrosit, diduga hal ini terjadi karena adanya peningkatan kualitas asupan nutrisi berupa SCFA selama 30 hari pada perlakuan sinbiotik dan prebiotik, yang secara langsung akan meningkatkan jumlah eritrosit, dan kemudian akan berdampak pada peningkatan hematokrit.
Penurunan nilai hematokrit pada hari ke-34 terjadi pada empat perlakuan yang diberikan infeksi A.hydrophila. Hal ini sesuai dengan hasil penelitian Ziskowski et al., (2008) bahwa infeksi bakteri dapat menurunkan jumlah hematokrit pada ikan winter flounder (Pseudopleuronectes americanus).

\section{Diferensial Leukosit}

Parameter diferensial leukosit yang diamati pada penelitian ini meliputi monosit, limfosit, serta neutrofil. Nilai yang diperoleh reltif bervariasi pada setiap perlakuan.

\section{Monosit}

Monosit merupakan parameter mononuklear disamping makrofag yang berhubungan dengan sistem imun nonspesifik pada proses fagositik dan bekerja sama dengan komponen imun lainnya seperti neutrofil, mast sel, makrofag, B lymposit, T lymposit, interleukin (Lv-yun, 2013). Hasil dari perhitungan monosit ditampilkan pada Gambar 


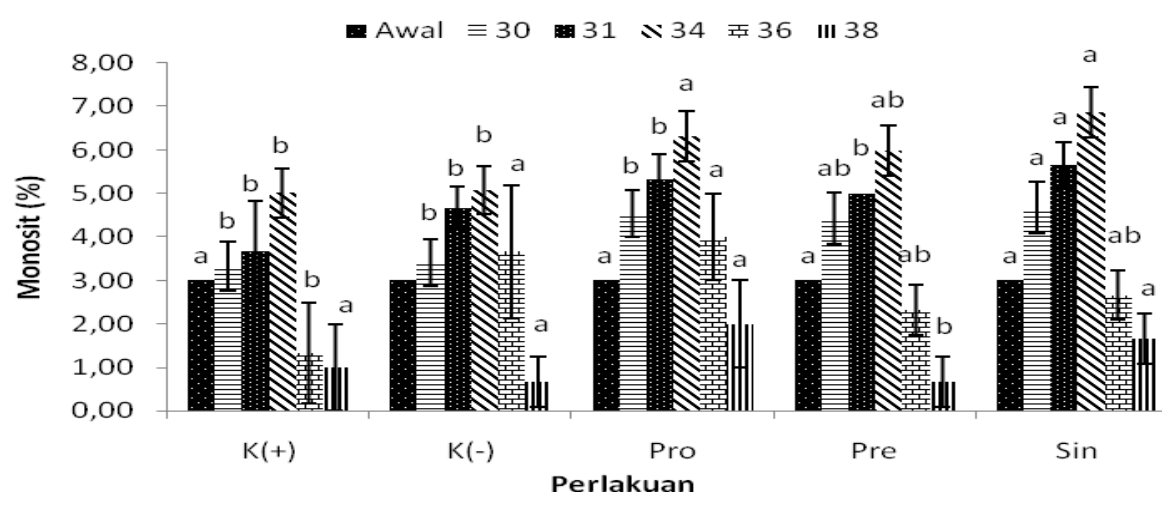

Gambar 3. Nilai monosit darah ikan uji pada berbagai perlakuan

Monosit pada pengambilan sampel awal menunjukkan nilai yang sama pada semua perlakuan yaitu $3,00 \pm 0,00$ kemudian mengalami peningkatan pada hari ke-30, dan mencapai nilai tertinggi pada hari ke34. Berdasarkan hasil uji Duncan, terdapat beda nyata antara perlakuan sinbiotik, probiotik, dengan $\mathrm{K}(-)$ dan $\mathrm{K}(+)$ pada hari ke-34 dengan masingmasing nilai sebesar $6,87 \pm 0,58$; $6,33 \pm 0,58 ; 5,07 \pm 0,55$; dan 5,01 $\pm 0,58$.

Penurunan monosit terjadi mulai hari ke-36, hasil uji Duncan menunjukkan pada hari ke-36 tidak menunjukan perbedaan yang nyata antara sinbiotik dengan $\mathrm{K}(+)$.

Peningkatan nilai monosit pada hari ke 34 menunjukkan sudah adanya pengaruh dari infeksi A.hydrophila pada $\mathrm{K}(+)$, probiotik, prebiotik serta sinbiotik, sehingga terjadi penambahan jumlah monosit dalam darah ikan, hal ini terkait dengan peran monosit sebagai makrofag yaitu sel fagosit utama untuk menghancurkan partikel asing dan jaringan mati.

Penurunan monosit mulai hari ke-36 diduga terjadi karena sel monosit mulai keluar dari sirkulasi darah, selanjutnya masuk ke jaringan yang terinfeksi dengan berdiferensiasi menjadi makrofag yang berperan dalam memfagosit dan menyajikan antigen kepada sel limfosit.

\section{Limfosit}

Limfosit merupakan sel yang berfungsi mengenali berbagai antigen, baik intraselular maupun ekstraselular. Sel ini berperan utama dalam sistem imun spesifik Hasil perhitungan limfosit ditampilkan pada Gambar 4 


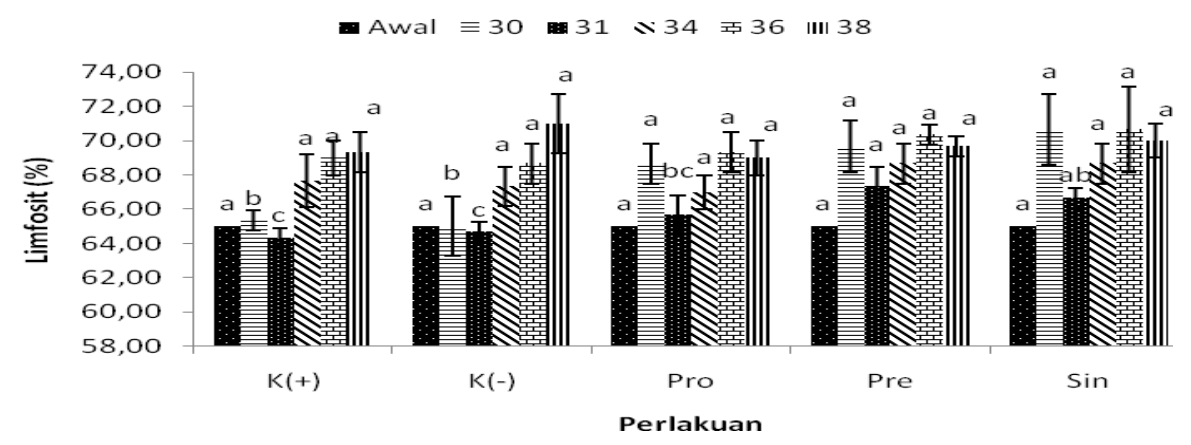

Gambar 4. Nilai limfosit ikan uji pada berbagai perlakuan

Nilai limfosit pada pengamatan awal menunjukkan nilai yang sama pada semua perlakuan yaitu sebesar $65,00 \pm 0,00$. Peningkatan mulai terjadi setelah tiga puluh hari pemberian pakan perlakuan, hasil uji Duncan menunjukkan beda nyata antara perlakuan sinbiotik, prebiotik, probiotik dengan $\mathrm{K}(-)$ dan $\mathrm{K}(+)$, masing-masing sebesar $\quad 70,67 \pm 2,08 ; \quad 69,67 \pm 1,53$; $68,67 \pm 1,15 ; \quad 65,00 \pm 1,73 \quad$ serta $64,33 \pm 0,58$. Penurunan limfosit terjadi pada hari ke 31, namun hasil uji lanjut menunjukkan terdapat beda nyata antara perlakuan dengan kontrol, dengan nilai sebesar $66,67 \pm 0,58$; $67,33 \pm 1,15 ; \quad 65,57 \pm 1,15 ; \quad 64,67 \pm 0,58$; serta $64,33 \pm 0,58$. Penurunan limfosit diduga tubuh ikan memberi respon tanggap kebal terhadap adanya infeksi A.hydrophila yang masuk ke dalam tubuh.

Limfosit, terdiri dari sel $\mathrm{T}$ pada imunitas selular, dan sel $\mathrm{B}$ pada imunitas humoral. Sel CD4+ dan $\mathrm{T}$ helper pada imunitas humoral akan bereaksi dengan sel B merangsang proliferasi dan diferensiasi sel. Sel CD4+ pada imunitas seluler berfungsi mengaktifkan makrofag untuk menghancurkan mikroba intraseluler
(Iwama, 1996). Perkembangan sel B dan Sel $\mathrm{T}$ berawal dari sel induk sumsum tulang, jalur sel B akan masuk ke sumsum tulang selanjutnya sel B akan matang dan masuk ke darah, sedangkan jalur sel $\mathrm{T}$ akan masuk ke thimus, sel $\mathrm{T}$ matang dan masuk ke darah dan limfa, Sel T dan sel B akan mengenali benda asing (antigen) serta membedakannya dengan jaringan sendiri berkat adanya $\mathrm{T}$ cel reseptor (TCR).

Berbeda dengan monosit, limfosit tidak bersifat fagositik tetapi berperan penting dalam pembentukan antibodi (Bratawidjaja, 2006). Pernyataan ini merupakan penjelasan dari data pada berbagai perlakuan, bahwa nilai terendah terjadi pada waktu setelah uji tantang. Diduga pada kondisi ini yang bekerja secara dominan adalah monosit sehingga differensiasi leukosit yang terjadi didominasi oleh monosit sehingga jumlah limfosit relatif berkurang. Pada hari ke-36 dan ke-38, dianggap merupakan kondisi pemulihan yang sebelumnya telah dijelaskan dan hal ini terlihat dari nilai limfosit yang meningkat, karena pada kondisi tersebut sel mulai membentuk antibodi 
agar ikan lebih tahan dari infeksi $A$. hydrophila berikutnya.

\section{Neutrofil}

Granulosit merupakan bagian dari leukosit dan diketahui terdiri dari 3 tipe, yakni neutrofil, eosinofil dan basofil. Neutrofil dan eonisofil adalah yang umum ditemui dalam banyak Gambar

- Awal $\equiv 30$ 뽀 31 «34 도 36 III 38

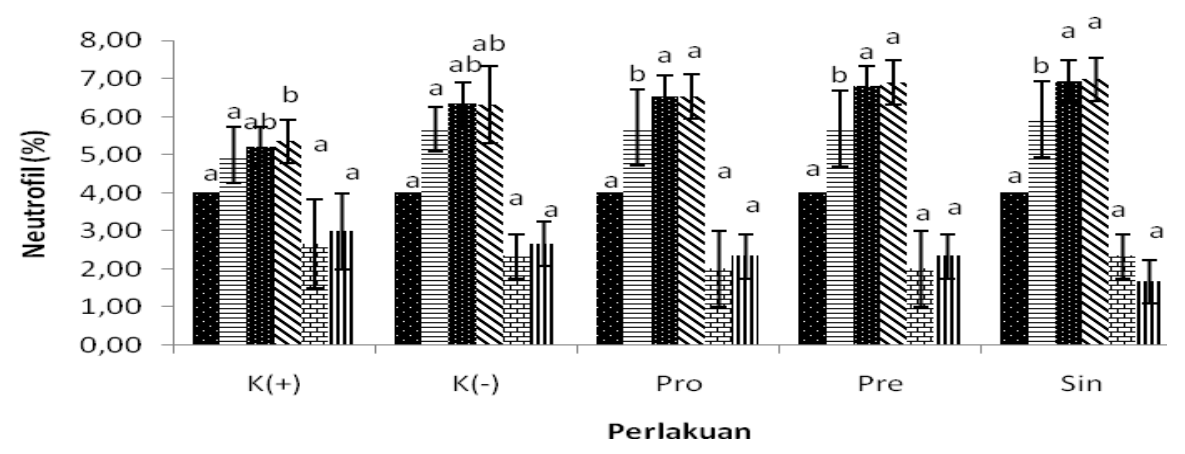

Gambar 5. Nilai neutrofil ikan uji pada berbagai perlakuan ditemui. Neutrofil adalah sel fagositik pertama yang tiba di lokasi infeksi dan beperan dalam pembunuhan serta degradasi mikroorganisme sebagaimana yang dilakukan dalam penyembuhan luka (Fraser et al., 2012). Hasil pengukuran neutrofil ditampilkan pada

Nilai neutrofil pada awal Pada saat inilah sel pertahanan fagositik pengambilan sampel menunjukkan nilai didominasi oleh neutrofil, tetapi yang sama yaitu 4,00 $\pm 0,00$. beberapa jam kemudian (7-8 jam) sel Peningkatan neutrofil terjadi mulai hari yang mendominasi adalah monosit ke-31 dan mencapai puncaknya pada (Iwama, 1996).

hari ke-34 dan hasil uji lanjut memberikan beda nyata antara perlakuan sinbiotik, prebiotik, probiotik dengan $\mathrm{K}(+)$. Neutrofil pada hari ke-30 tidak menunjukkan beda nyata, diduga hal ini terjadi karena pada hari ke-30 belum terjadi infeksi sehingga populasi neutrofil disimpan untuk keadaan darurat di dalam jaringan limfoid dari ginjal.

Neutrofil berperan dalam masalah fagositik sel patogen sebagaimana yang dilakukan oleh monosit namun demikian sel neutrofil bergerak lebih cepat dari monosit, dan sampai di daerah infeksi dalam 2-4 jam.

\section{KESIMPULAN}

Nilai hemoglobin, hematokrit pada perlakuan sinbiotik menunjukkan nilai yang lebih baik dibandingkan perlakuan lainnya. Diferensial leukosit yang terdiri dari limfosit, monosit serta neutrofil menunjukkan nilai yang bervariasi pada beberapa waktu pengamatan untuk semua perlakuan. 


\section{DAFTAR PUSTAKA}

Anderson DP and Siwicki AK. 1993. Basic hematology and serology for fish health programs. Paper presented in second symposium on diseases in Asean Aquaculture "Aquatic Animal Health and The Environment". Phuket, Thailand. $25-29^{\text {th }}$ October 1993. 17hlm.

Bauer AW, Kirby WMM, Sherris JC, and Turck M. 1966. Antibiotic susceptibility testing by a standardized single disk method. Am. $\quad J$. Clin. Pathol 36:493-496.

Bernardeau M, Vernoux JP, Dubernet SH and Guéguen M. 2008. Safety assessment of dairy microorganisms: The Lactobacillus genus. Food Microbiology 126: 278-285.

Blaxhall PC and Daisley KW. 1973. Routine haematologycal methods for use with fish blood. J. Fish Biology 5: 577 - 581.

Bratawidjaja KG. 2006. Imunologi Dasar. Edisi keenam. Balai Penerbitan Fakultas Kedokteran Universitas Indonesia. Jakarta.

Fraser TWK, Rønneseth A, Haugland GT, Fjelldal PG, Mayer I and H.I. Wergeland HI. 2012. The effect of triploidy and vaccination on neutrophils and B-cells in the peripheral blood and head kidney of $0+$ and $1+$ Atlantic salmon (Salmo salar L.) post-smolts. Fish \& Shellfish Immunology 33: 6066.
Gropper SS, Jack LS and James LG. 2009. Advanced nutrition and human metabolism. $5^{\text {th }} \mathrm{Ed}$. PrePress PMG. Canada.

Harikrishnan R, Balasundaram $\mathrm{C}$ and Heo M.-S. 2012. Effect of Inonotus obliquus enriched diet on hematology, immune response, anddisease protection in kelp grouper, Epinephelus bruneus against Vibrio harveyi. Aquaculture, 344-349: 48-53.

Hernandez $\mathrm{OH}$, Muthaiyan A, Moreno FJ, Montilla A, M.L. Sanz ML and Ricke SC. 2012. Effect of prebiotik carbohydrates on the growth and tolerance of Lactobacillus. Food Microbiology 30: 355 - 361.

Iwama G. 1996. The fish immune system. Academic press, San Diego-London-Boston-New York-Sydney-Tokyo-Toronto. 68-95, 185-222 p.

Lv-yun Zhu, Li Nie, Guan Zhu, Li-xin Xiang, Jian-zhong Shao. 2013. Advances in research of fish immune-relevant genes: A comparative overview of innate and adaptive immunity in teleosts. Developmental \& Comparative Immunology 39:39-62

Mathious AS, Gatesoupe FJ, Hervi M, Metailler $\mathrm{R}$ and Ollevier F.. 2006. Effect of dietary inulin and oligosaccharides as prebiotiks for weaning turbot, Psettanational maxima. $J$. Aquaculture International 143: $219-229$. 
Merrifield DL, Dimitroglou A, Foey A, Davies SJ, Baker RTM, Bøgwald J, Castex M and Ringø E. 2010. Review: The Current status and future focus of probiotic and prebiotik applications for salmonids. Aquaculture 302: 1-18.

Putra AN. 2010. Aplikasi probiotik, prebiotik dan sinbiotik untuk meningkatkan kinerja pertumbuhan ikan nila (Oreochromis niloticus). Tesis. Bogor. Sekolah Pascasarjana, Institut Pertanian Bogor.

Rey A, Verján N, Ferguson HW and Iregui C. 2009. Pathogenesis of Aeromonas hydrophila strain KJ99 infection and its extracellular products in two species of fish. Veterinary Record 164: 493-499.

Wartono Hadie, Lies Emmawati, Angela Mariana Lusiastuti. 2010. Peningkatan produksi benih ikan patin di unit pembenihan rakyat (UPR) melalui penerapan kekebalan bawaan (Maternal immunity). Prosiding forum inovasi teknologi akuakultur. Pusat Riset Perikanan Budidaya.

Wedemeyer GA and Yasutake WT. 1977. Clinical methods for the assessment of the effect environment stress on fish health. Technical papers of the US.fish and wildfield services. US. Depart. of the interior fish and wildlife service 89: 1-17.

Ziskowski J, Mercaldo-Allen R, Pereira JJ, Kuropat C, Goldberg R. 2008. The effects of fin rot disease and sampling method on blood chemistry and hematocrit measurements of winter flounder,Pseudopleuronectes americanus from New Haven Harbor (1987-1990). Marine Pollution Bulletin 56:740-750. 